\title{
Performance evaluation of the companies constructing highways
}

\author{
Anna Minnullina ${ }^{1, *}$, and Ruslan Minnullin ${ }^{1}$ \\ ${ }^{1}$ Tyumen Industrial University, Volodarskogo St., 38, Tyumen, 625000, Russia
}

\begin{abstract}
Methodical bases for performance evaluation of the road construction company which is carrying out highway construction are based on integrated indicator calculation. This indicator considers interrelation of various internal and external environment factors. These factors are subdivided into three main groups by the authors: organizational and technological factors, technical factors and financial and economic factors. The suggested method of integrated indicator calculation for performance evaluation has been tested in the Tyumen road construction company. Testing confirms an opportunity to estimate the company position and utilization flexibility of calculation in practice.
\end{abstract}

\section{Introduction}

One of the most important reasons of the crisis phenomena in road industry is that like the whole Russian economy, it struggles to face a difficult reforming period. Analysis of the economic reforms in Russia shows that many of the suggested road-building transformations haven't been carried out. Moreover, some late changes (new organizational structures; former economic ties disruption; disintegration of large regional and industrial road-building associations into small road-building companies; outdated labour management which isn't conforming to modern requirements; the developed pricing system which doesn't reflect real contractor expenses; use of outdated technologies, etc.) have produced a negative impact on a state and possibilities a road-building complex to function efficiently.

Most road building companies turned out to be not ready to function in new management conditions. Only an insignificant part of them adapted to new management conditions, however many companies have such an adaptation based on tax evasion, barter use, non-core operations.

The general condition of road-building companies, structural transformations, resources' provision, development of market relations ensure that overcoming a crisis situation in the road-building industry, transition to a new model of economic growth require new methodical approaches to increase their performance as primary and main element of market economy.

The works of such scientists as Bakanov M.I., Yefimova O.V., Kovalyov V.V., Pankov D.A., Razeberg B.A., Savitskaya G.V., Saifullin R.S., Sheremet A.D., etc are devoted to the issue of assessing road building company performance [1-14].

\footnotetext{
* Corresponding author: minnullinaay@yandex.ru
} 


\section{Methods}

According to the authors, building company performance in business terms of regional investment and construction complex development in many respects depends on interaction of various external and internal environment factor groups [10].

When forming and assessing the factor space influencing road building characteristics and road building company performance, it is required to judge from the following major prerequisites:

- the factors influencing road building company performance should be formed both in external, and in the internal environment;

- factor space formation should consider the interests of all participants of the project construction, namely: investor, building owner, general contractor and subcontractors.

As a result of the major prerequisite consideration, the following major factors which are conditionally divided into three main groups have been formulated: organizational and technological, technical and financial and economic (Table 1).

Table 1. Major factors influencing road building company performance.

\begin{tabular}{|c|c|c|c|}
\hline \multirow{2}{*}{$\begin{array}{l}\text { No. in } \\
\text { sequence }\end{array}$} & \multicolumn{3}{|c|}{ Factor name } \\
\hline & $\begin{array}{l}\text { I. Organizational And } \\
\text { Technological }\end{array}$ & II. Technical & $\begin{array}{l}\text { III. Financial And } \\
\text { Economic }\end{array}$ \\
\hline 1. & $\begin{array}{l}\text { Quality of design estimate } \\
\text { documentation }\end{array}$ & $\begin{array}{l}\text { The degree of deviation } \\
\text { of standard decisions } \\
\text { from the actual ones }\end{array}$ & Company liquidity \\
\hline 2. & $\begin{array}{l}\text { Flexibility of } \\
\text { organizational structure in } \\
\text { the road building } \\
\text { company }\end{array}$ & $\begin{array}{l}\text { The extent of new } \\
\text { material uses }\end{array}$ & $\begin{array}{l}\text { Efficient use of } \\
\text { production potential }\end{array}$ \\
\hline 3. & Product competitiveness & $\begin{array}{l}\text { Depreciation of fixed } \\
\text { assets }\end{array}$ & $\begin{array}{l}\text { Financial and material } \\
\text { stock level }\end{array}$ \\
\hline 4. & $\begin{array}{l}\text { Highway construction } \\
\text { period }\end{array}$ & $\begin{array}{l}\text { Development of } \\
\text { transport lay-outs }\end{array}$ & $\begin{array}{l}\text { System of settlements } \\
\text { with the third-party } \\
\text { companies }\end{array}$ \\
\hline 5. & Rate of turnover & Crew operating mode & $\begin{array}{l}\text { Forms of motivation } \\
\text { for quality }\end{array}$ \\
\hline 6. & $\begin{array}{l}\text { Standards of fist-line } \\
\text { construction organization }\end{array}$ & $\begin{array}{l}\text { The rate of mechanical } \\
\text { operations }\end{array}$ & $\begin{array}{l}\text { Investment } \\
\text { profitability }\end{array}$ \\
\hline 7. & $\begin{array}{l}\text { Subcontractors' working } \\
\text { interest at the project } \\
\text { construction }\end{array}$ & $\begin{array}{l}\text { Frequency in labor costs } \\
\text { deviation }\end{array}$ & Own funds coverage \\
\hline 8. & Operation seasonality & $\begin{array}{l}\text { The degree of } \\
\text { machinery and } \\
\text { mechanism provision }\end{array}$ & $\begin{array}{l}\text { Forms and methods of } \\
\text { financing and } \\
\text { investment }\end{array}$ \\
\hline 9. & Investors & $\begin{array}{l}\text { Degree of construction } \\
\text { unit reliability }\end{array}$ & $\begin{array}{l}\text { Degree of reliability of } \\
\text { supplied resources }\end{array}$ \\
\hline 10. & $\begin{array}{l}\text { Penalty application to } \\
\text { prevent contractual term } \\
\text { violation }\end{array}$ & $\begin{array}{l}\text { Dispersed nature of } \\
\text { operation sites }\end{array}$ & $\begin{array}{l}\text { Compensation scheme } \\
\text { (forms of material } \\
\text { encouragement) }\end{array}$ \\
\hline 11. & End product output & $\begin{array}{l}\text { Time of the operation } \\
\text { spread }\end{array}$ & $\begin{array}{l}\text { Contractual } \\
\text { arrangement terms } \\
\text { with building owners }\end{array}$ \\
\hline 12. & $\begin{array}{l}\text { The use of the existing } \\
\text { quality standards }\end{array}$ & $\begin{array}{l}\text { Condition of roads in the } \\
\text { region }\end{array}$ & Risk level \\
\hline 13. & Manual labour ratio & Unit production capacity & Product sales volume \\
\hline
\end{tabular}




\begin{tabular}{|c|l|l|l|}
\hline 14. & $\begin{array}{l}\text { The degree of regularity } \\
\text { of pace in resources } \\
\text { consumption }\end{array}$ & Operation technology & Product sales profit \\
\hline 15. & $\begin{array}{l}\text { Quantitative and } \\
\text { qualitative road-building } \\
\text { machine fleet }\end{array}$ & Area of construction & Cost of products sold \\
\hline 16. & $\begin{array}{l}\text { Regional transportation } \\
\text { development }\end{array}$ & Performance labor input & \\
\hline 17. & Specialization level & & \\
\hline 18. & Business unit capacity & & \\
\hline
\end{tabular}

In order to justify the choice of organizational and economic reasons from the obtained totality, the following twelve major factors (Table 2) have been determined.

Table 2. Factors influencing road building company performance chosen for the expert poll.

\begin{tabular}{|c|l|c|}
\hline No & \multicolumn{1}{|c|}{ Factor name } & Designation \\
\hline 1. & The scope of installation and construction works & $\mathrm{X}_{1}$ \\
\hline 2. & Investors & $\mathrm{X}_{2}$ \\
\hline 3. & Operation seasonality & $\mathrm{X}_{3}$ \\
\hline 4. & Efficient use of a company capital & $\mathrm{X}_{4}$ \\
\hline 5. & Construction product quality & $\mathrm{X}_{5}$ \\
\hline 6. & Information resources coverage & $\mathrm{X}_{6}$ \\
\hline 7. & Degree of reliability of supplied resources & $\mathrm{X}_{7}$ \\
\hline 8. & $\begin{array}{l}\text { Subcontractors' participation ratio in the project } \\
\text { construction }\end{array}$ & $\mathrm{X}_{8}$ \\
\hline 9. & The rate of mechanical operations & $\mathrm{X}_{9}$ \\
\hline 10. & Financial and material stock level & $\mathrm{X}_{10}$ \\
\hline 11. & Dispersed nature of operation sites & $\mathrm{X}_{11}$ \\
\hline 12. & The regularity of pace in company performance & $\mathrm{X}_{12}$ \\
\hline
\end{tabular}

All the mentioned factors characterize the use of road building company potential, an organizational form of operation under various conditions.

When quantitatively assessing the influence of the revealed significant factors on the road building company performance, it is required to judge from the following prerequisites:

- quality management of road-building production must be carried out judging the assessment of each resource type on the basis of local, private, complex and integrated indicators;

- increase in company performance depends on specific conditions where it is carried out;

- road building company performance depends on a reasonable combination of all types of resources;

- the end products should conform to constantly increasing consumers' requirements, international standards, specification and technical documentation requirements;

- company performance should be defined by an integrated indicator of efficiency which characterizes compliance of external and internal environment and probability to obtain sufficient output parameters of finished goods.

To assess quantitative influence of factors on the company performance, it is required to estimate material resources utilization rate since it predetermines ensuring output parameters of the end products which define the degree of consumers' satisfaction with the construction products, supply and demand of this type of finished goods and material resources form the corresponding qualitative characteristics. The production quality system places the highest value to it. Therefore, it is assumed to define a defect level indicator for material resources: 


$$
Y_{\text {def.m.res }}=\frac{\sum_{i=1}^{n}\left(C_{\text {def.m.res }}^{i}+C_{\text {lab }}^{i}\right)}{\sum_{i=1}^{n} C_{m . r e s}^{i}} \rightarrow \min
$$

$i=\overline{1, n}$ is the number of a construction site; $C_{\text {def.m.res }}^{i}$ is the cost of $i$-object defective material resources; $C_{\text {lab }}^{i}$ is the cost of $i$-object laboratory researches; $C_{m . r e s}^{i}$ is the cost of $i$ object material resources.

The quality of the made production is directly connected with the quality of the used material resources, therefore, the level of defective production is calculated here as well:

$$
Y_{\text {def.prod }}=\frac{\sum_{i=1}^{n}\left(C_{\text {def.prod }}^{i}+C_{\text {recons }}^{i}\right)}{\sum_{i=1}^{n} C_{I C W}^{i}} \rightarrow \min
$$

$C_{\text {def.prod }}^{i}$ is the cost of $i$-object defective production; $C_{\text {recons }}^{i}$ is the cost of $i$-object reconstruction; $C_{I C W}^{i}$ is the cost of $i$-object installation and construction works (ICW).

According to the authors, the factors characterizing labour resources utilization are estimated, first of all, by an indicator of production stuff skill level:

$$
Y_{w \cdot w}=\frac{\sum_{i=1}^{n} \sum_{k=1}^{h}\left(W_{k}^{i} P_{k}^{i}\right)}{\sum_{i=1}^{n} W^{i} P_{a v . w}^{i}} \rightarrow \max
$$

$K=\overline{1, h}$ is workers' wage categories; $W_{k}^{i}$ is the number of $k$-class workers in an $i$-object; $P_{k}^{i}$ is an $i$-object worker class; $W^{i}$ is the number of $i$-object workers; $P_{a v . w}^{i}$ - is an average wage category of a work.

This indicator gives an opportunity to estimate the level of labour resource capability in a road building company.

The efficiency of the work performed depends on the manual skill, production potential ratio, the use of equipment, technology and innovation. All these characteristics are included in the concept of technical resources. They determine the efficient use of business assets, innovations, equipment and technologies in various situations and are estimated by a potential utilization ratio by a road-building company:

$$
Y_{\text {pot.rat }}=\sum_{i=1}^{n} \frac{P C^{i}}{P C} \rightarrow \max
$$

$P C^{i}$ is $i$-object production capacities; $P C$ is production capacities of a company.

A type of a situation when the company can perform and a type of internal and external environment compliance when forming qualitative output characteristics depends on the economic sustainability and stability of the road-building company under specific production conditions. Therefore, financial resources efficiency is determined by means of a collection level indicator:

$$
Y_{\text {ind }}=\frac{\sum_{i=1}^{n} \sum_{l=1}^{L} W_{l . p}^{i}}{\sum_{i=1}^{n} \Sigma_{l=1}^{L} P_{l}^{i} C_{l . p}^{i}} \rightarrow \max
$$

$l=\overline{1, L}$ is ICW types; $C_{l . p}^{i}$ is an actual sum, paid for $l$-type ICW at $i$-object; $P_{l}^{i}$ is the volume of the performed $l$-type ICW at $i$-object; $C_{l}^{i}$ is the cost of $l$-type ICW at $i$-object.

The first three types of resources (material, labor, technical) determine industrial processes (basic, off-line, service), construction operation technology, organization forms and managerial forms for these processes. Financial resources define a type of a situation, external and internal environment conditions and a compliance degree of external and internal environment to building company performance.

A compliance degree of external and internal environment when producing the end goods is defined by the risk level to exceed the project periods and project expenses when constructing sites.

The overall risk for a building company under these conditions can be estimated by the 
deviation risks from the project data:

$$
Y_{T}=\left(\prod_{i=1}^{n}\left(Y_{t}^{i} Y_{s}^{i}\right)\right)^{1 / 2 n} \rightarrow \min
$$

$Y_{t}^{i}, Y_{s}^{i}$ is deviation risks for an i-object according to the project periods and project expenses.

The risk to exceed the project periods is expressed in the need to compensate various losses due to contractual obligations violation (penalty fees, stipulated damages, legal claims) with the growth of conditional and constant expenses for building companies and at opportunity costs risk development. To calculate it, the formula is used:

$$
Y_{t}=\max _{1 \leq i \leq n} \frac{T_{\text {prod }}^{i}}{T_{\text {prod }}^{i}+\Delta T_{i}} \rightarrow \max
$$

$T_{\text {prod }}^{i}$ is a project (standard, planned) period of constructing a site, in months; $\Delta T_{i}$ is a deviation in construction project period, in months.

The risk to exceed the project expenses is expressed in additional expenses due to project construction, but not stipulated by the design estimate documentation in the construction contract. This risk is calculated by the formula:

$$
Y_{s}=\max _{1 \leq i \leq n} \frac{s_{\text {prod }}^{i}}{s_{\text {prod }}^{i}+\Delta S_{i}} \rightarrow \min
$$

$S_{\text {prod }}^{i}$ is project (estimated) expenses on project construction, in thousand rubles.; $\Delta S_{i}$ is additional expenses, in thousand rubles.

To calculate an integrated (complex) indicator of company performance using criteria normalizing (standardization) method, the procedure of criteria normalization is made, that is the general dimension is given to all (n) optimality criteria, or in case it doesn't succeed, all criteria $\mathrm{y}_{\text {perf }}$ are presented in the form of nondimensional values $\delta_{i}$, that is $\mathrm{y}_{\text {perf }}, i=\overline{1, n}$ transition.

Transition from coefficient multidimension is carried out according to the following scheme:

$$
\delta_{i j}=\left\{\begin{array}{c}
\frac{y_{i j}}{y_{i}^{o}}, i \in M_{1} \\
\frac{y_{i}^{o}}{y_{i j}}, \in M_{2} \\
\in[0,1]
\end{array}\right.
$$

$i=\overline{1, n}$ is the number of estimated criteria (indicators) of performance; $j=\overline{1, m}$ is the number of time periods; $y_{i j}$ is the $i$-criterion performance value for the calculated time period; $y_{i}^{o}$ is the extreme (ideal, calibration) value of $i$ - criterion performance within $m$ periods of time defined as:

$$
y_{i}^{o}=\left\{\begin{array}{c}
\operatorname{maxa}_{i j}, i \in M_{1} \\
1 \leq j \leq m \\
\operatorname{mina}_{i j}, i \in M_{2} \\
1 \leq j \leq m
\end{array}\right.
$$

$M_{1}, M_{2}$ is a subset of performance criteria which are respectively maximized and minimized; $\left|M_{1}\right|+\left|M_{2}\right|=M, M_{1} \cap M_{2}=\varnothing$.

As an integrated evaluation of company performance criterion an additive compromise scheme is used:

$$
\mathrm{y}_{\text {perf }}=\sum_{i=1}^{n} \lambda_{i} \delta_{i j} \rightarrow \underset{1 \leq j \leq m}{\max }
$$


$\lambda_{i}$ is a relative coefficient of importance (significance) for i-criterion.

Based on the Bernoulli-Laplace insufficient reason criterion: $\lambda_{1}=\lambda_{2}=\cdots=\lambda_{n}=\frac{1}{n}=$ const, it is assumed that any local criteria is of no more significance than others.

Thus, the calculation formula for an integrated indicator of the company performance will be as follows:

$$
\mathrm{y}_{\text {perf }}=\frac{1}{n} \times \sum_{i=1}^{n} \delta_{i j} \rightarrow \begin{gathered}
\max \\
1 \leq j \leq m
\end{gathered}
$$

When operating, any road building company should know the possible limits for which its integrated indicator of operating efficiency may change defining:

- the degree of compliance or non-compliance to external and internal environment when forming end products;

- efficient use of accumulated potential and available resources.

The given indicator should resolve the following issues:

- determination of consumer demand for end products, compliance to the international standards and company competitiveness in the finished construction product market;

- definition of the total cost for end product creation;

- determination of temporary parameters for end product creation considering investor and market requirements;

- evaluation of the investment and construction complex performance through the compliance to external and internal environment conditions.

To achieve it, a road-building company based on the economic activity analysis requires to carry out performance testing in order to identify the existing specifics of its efficiency through an integrated indicator of the road-building company performance and the relevant action development to ensure it in real production.

In economic science, there are scales based on subjective estimates by $T$. Saati, O. Larichev, D. Torstoun's. The conducted expert survey, the quantitative analysis of factor space influence and analysis of situations where a road-building company may find itself, allowed to define an interval within which the situation is sustainable and stable and performance only slightly changes, being equal to 0,2 .

Thus, five intervals of road building company performance can be conditionally defined, based on the value of an integrated performance indicator (Table 3).

Table 3. Basic intervals of road building company performance.

\begin{tabular}{|c|c|c|c|c|c|}
\hline Name & \multicolumn{5}{|c|}{ Interval areas of company performance evaluation } \\
\hline Interval estimate $\mathrm{y}_{\text {perf }}$ & {$[0-0.2]$} & $(0.2-0.4]$ & $(0.4-0.6]$ & $(0.6-0.8]$ & $(0.8-1]$ \\
\hline Business situation (BS) & $B S_{5}$ & $B S_{4}$ & $B S_{3}$ & $B S_{2}$ & $B S_{1}$ \\
\hline
\end{tabular}

Depending on a situation type it is possible to track and assess the deviation degree of the key technical and economic indicators of the road-building company performance based on the potential end result (situation Pi).

Transition to a less favorable organizational and economic situation predetermines the increase in different types of losses, decrease in product quality levels and leads to losses formation. Therefore, a road building company should estimate its operation results in advance for consideration of various organizational and economic situations and define the ways to deal with the current situation transiting to a more stable zone. In order to achieve it, it is necessary to consider various transition options from less favorable to a more favorable operation situation. It will allow choosing the most effective option for construction system 
development, avoiding different types of risks, developing and choosing the strategy of its development and obtaining the required end performance results.

\section{Assessment and Results}

Evaluation of road building company performance was carried out on the example of a structural division of Tyumen Regional Road Construction and Maintenance Enterprise jointstock company - the road maintenance and construction department No. 7 (in abbreviated form RMCD-7 of JSC TRRCME) operating in the road building service market of the Tyumen region in Russia that gives the opportunity to estimate the quantitative influence of significant external and internal environment factors. In this regard, using the formulas (112), calculations of an integrated indicator of RMCD-7 performance as of 2013-2017 were carried out, using a criteria normalizing method (Table 4 and 5).

Table 4. Optimality criterion normalization.

\begin{tabular}{|c|l|c|c|c|c|c|c|}
\hline \multirow{2}{*}{$\begin{array}{c}\text { No. in } \\
\text { sequence }\end{array}$} & \multirow{2}{*}{ Performance criterion $\left(\mathrm{y}_{i j}\right)$} & \multicolumn{5}{|c|}{ Period of time } & $\begin{array}{c}\text { Optimum } \\
\text { value for } \\
\text { performance } \\
\text { criterion } \\
\left(\mathrm{Y}_{i}^{o}\right)\end{array}$ \\
\cline { 3 - 8 } & & 2013 & 2014 & 2015 & 2016 & 2017 & 0.08 \\
\hline 1 & $Y_{\text {def.m.res }} \rightarrow \min$ & 0.105 & 0.16 & 0.15 & 0.105 & 0.08 & 0.03 \\
\hline 2 & $Y_{\text {def.prod }} \rightarrow \min$ & 0.08 & 0.04 & 0.06 & 0.03 & 0.05 & 0.03 \\
\hline 3 & $Y_{\text {w.w }} \rightarrow \max$ & 0.917 & 0.84 & 1.17 & 0.954 & 0.961 & 1.17 \\
\hline 4 & $Y_{\text {pot.rat }} \rightarrow \max$ & 0.983 & 0.925 & 0.955 & 0.94 & 0.953 & 0.983 \\
\hline 5 & $Y_{\text {ind }} \rightarrow \max$ & 0.943 & 0.755 & 0.916 & 0.817 & 0.83 & 0943 \\
\hline 6 & $Y_{T} \rightarrow \min$ & 1.08 & 1 & 0.87 & 1.15 & 0.886 & 0.87 \\
\hline
\end{tabular}

Table 5. Calculations of an integrated indicator of RMCD-7 performance.

\begin{tabular}{|c|l|c|c|c|c|c|}
\hline \multirow{2}{*}{ No } & \multirow{2}{*}{ Performance criterion $\left(\mathrm{y}_{i j}\right)$} & \multicolumn{5}{|c|}{ Period of time } \\
\cline { 3 - 7 } & & 2013 & 2014 & 2015 & 2016 & 2017 \\
\hline 1 & $Y_{\text {def.m.res }} \rightarrow \min$ & 0.76 & 0.50 & 0.53 & 0.76 & 1.00 \\
\hline 2 & $Y_{\text {def.prod }} \rightarrow \min$ & 0.38 & 0.75 & 0.50 & 1.00 & 0.60 \\
\hline 3 & $Y_{\text {w.w }} \rightarrow \max$ & 0.78 & 0.72 & 1.00 & 0.82 & 0.82 \\
\hline 4 & $Y_{\text {pot.rat }} \rightarrow \max$ & 1.00 & 0.94 & 0.97 & 0.96 & 0.97 \\
\hline 5 & $Y_{\text {ind }} \rightarrow \max$ & 1.00 & 0.80 & 0.97 & 0.87 & 0.88 \\
\hline 6 & $Y_{T} \rightarrow \min$ & 0.81 & 0.87 & 1.00 & 0.76 & 0.98 \\
\hline Total & $\mathrm{y}_{i j}$ & 4.73 & 4.58 & 4.98 & 5.16 & 5.25 \\
\hline Integrated indicator of performance $\mathrm{Y}_{\text {perf }}$ & $\mathbf{0 . 7 9}$ & $\mathbf{0 . 7 6}$ & $\mathbf{0 . 8 3}$ & $\mathbf{0 . 8 6}$ & $\mathbf{0 . 8 8}$ \\
\hline Business situation $(B S)$ & $B S_{2}$ & $B S_{2}$ & $B S_{1}$ & $B S_{I}$ & $B S_{I}$ \\
\hline
\end{tabular}

Thus, performance in 2017 accounts for $88 \%$ of the potential, which corresponds to the situation of high economic stability $\left(B S_{l}\right)$.

\section{Conclusions}

As a result of the conducted research, it can be concluded that RMCD-7 performance is carried out in normal economic conditions. Since 2015 to the present day the company is almost constantly in its high economic stability (П1), except for 2013-2014 (a situation of average economic stability (П2) characterized by the growth of additional costs for end 
product creation; an average level of company financial performance; acceptable minimum level of finished goods quality; an average capacity utilization of a road building company; considerable influence of risk factors and uncertainty.

According to the authors' opinion, the increase in road building company performance can be carried out based on three possible scenarios [11]:

Scenario 1. In case of fixed production volumes of the end product, the plan of actions is defined that increases production quality through improvement of consumer-oriented characteristics in construction products:

$$
F_{1}(x)=Y_{q}(x) \rightarrow \max _{\left\{\begin{array}{c}
x \in S \\
V=\text { const }
\end{array}\right.}
$$

$V$ is the volume of the end product; $Y_{q}$ is the quality level; $S$ is a constraint system which each decision $x$ (plan of actions) should satisfy with.

Scenario 2. In case of a fixed quality level of the company end product, the plan of actions is defined that increases performance on the basis of increase in end product volumes and creation of more favorable conditions in the external environment:

$$
F_{2}(x)=V(x) \rightarrow \max _{\left\{Y_{q}=\right.\text { const }} \underset{x}{ }
$$

Scenario 3. A complex option considering a reasonable combination of the first two:

$$
F_{3}(x)=Y\left(Y_{q}(x) V(x) \rightarrow \max , x \in S\right.
$$

The given options for potential road building company development should be reasonably combined based on particular situations.

This approach allows to logically track a formation chain of building company performance considering the influence of the end product quality.

\section{References}

1. O.V. Efimova, How to analyze the financial situation of an enterprise (2014)

2. O.V. Efimova, The financial analysis (2010)

3. V.V. Kovalev, Methods for evaluating investment projects (2010)

4. V.V. Kovalev, Vit.V. Kovalev, Finance of enterprises (2016)

5. D.A. Pankov, Modern methods of analyzing the financial situation of an enterprise (2005)

6. G.A. Savickaya, Analysis of the economic activity of the enterprise (2017)

7. A.D. Sheremet, Finance of enterprises (2008)

8. A.D. Sheremet, M.I. Bakanov, Theory of Economic Analysis (2011)

9. A.D. Sheremet, V.P. Suiz, The Audit (2017)

10. E.N. Garmanov, Economy of road construction (2015)

11. A. Minnullina, V. Vasiliev, E3S Web of Conferences 33, 03060 (2018), https://doi.org/10.1051/e3sconf/20183303060

12. A. Mottaeva, A. Zheltenkov, E3S Web of Conferences, 33, 01038 (2018) doi: 10.1051/e3sconf/20183301038

13. I. Potekhin, V. Mischenko, A. Mottaeva, A. Zheltenkov, E3S Web of Conferences, 33, 03020 (2018) doi: 10.1051/e3sconf/20183303020

14. A. Mottaeva, J. Ćetković Advances in Intelligent Systems and Computing, 692, 11511159 (2018) doi: 10.1007/978-3-319-70987-1_123 